\title{
ARTICLE \\ Economic crisis, COVID-19 pandemic, and the Greek model of capitalism
}

\author{
Georgios Maris $^{1}$ (D) Floros Flouros $^{1}$
}

Received: 27 April 2021 / Accepted: 10 October 2021 / Published online: 21 October 2021

(C) Japan Association for Evolutionary Economics 2021

\begin{abstract}
In this paper, we use varieties of capitalism as an analytical tool to understand the main characteristics of the Greek model of capitalism. The main purpose of this paper is twofold: first, to study the evolution of the country's economic performance through the theoretical approach of varieties of capitalism; second, highlighting the performance of institutions to understand how the main characteristics of the Greek model of capitalism have been changed during last years. The main questions of the article are: How the Greek model of capitalism affected not only the institutional but also the economic performance in Greece? Does the COVID-19 pandemic influence the model of capitalism in Greece? By applying the principles of the comparative political economy, we will be able to draw conclusions regarding the institutional performance in Greece and the characteristics of the Greek model of capitalism. As we will argue, the Greek model of capitalism was shaped by the power of ideas of country's political leaders since 1980s. These ideas influenced the characteristics of the Greek model of capitalism creating a rather exceptional institutional framework unable to support long- run economic growth in the country. This exceptionalism is associated with an institutional asymmetry in relation with other member states and characterizes the Greek model of capitalism not only as the main cause for the economic crisis, but also as a significant obstacle to any recovery efforts, especially during COVID-19 pandemic.
\end{abstract}

Keywords Greece · Economic crisis · Varieties of capitalism · Political economy · COVID-19

JEL Classification $\mathrm{E} 020 \cdot \mathrm{H} 63 \cdot \mathrm{H} 120 \cdot \mathrm{P} 1$

Georgios Maris

gmaris@aegean.gr

Floros Flouros

f.flouros@aegean.gr

1 Department of Mediterranean Studies, "7th March" Campus Building, University of the Aegean, 1, Dimokratias Avenue, 85132 Rhodes, Greece 


\section{Introduction}

The last Greek economic crisis affected all aspects of the social life in the country, worsening the economic indicators and the relationship between the citizens and the state. Several studies have been published during last year's highlighting various aspects of the Greek economic crisis (see among others, Maris et al. 2021; Pagoulatos 2020; Lapavitsas 2019; Featherstone 2011). All these approaches provided specific answers regarding the main causes of the eruption of the Greek economic crisis as well as the proposals to deal with. In this article, we will try to shed light on the economic performance of Greece using the theoretical approach of the varieties of capitalism. More specifically, we are going to study the main characteristics of the Greek model of capitalism focusing on the role of the state which affects all aspects of both political and economic environment in the country. This paper complements other efforts that have been developed during last decade trying to emphasize on the significant effect of institutions to the Greek failure to support sustainable growth rates (Maris 2021; Maris et al. 2021; Sklias and Maris 2013). The approach of varieties of capitalism will be used as a tool to understand not only the reasons of the eruption of the Greek economic crisis, but also the long-run institutional weaknesses and the main characteristics of the Greek model of capitalism. Thus, the main purpose of this paper is twofold: first, to study the evolution of the country's economic performance through the theoretical approach of varieties of capitalism; second, highlighting the performance of institutions to understand how the main characteristics of the Greek model of capitalism have been changed during last years. The main questions of the article are: How the Greek model of capitalism affected not only the institutional but also the economic performance in Greece? Does the COVID-19 pandemic influence the model of capitalism in Greece? By applying the principles of the comparative political economy, we will be able to draw conclusions regarding the institutional performance in Greece and the characteristics of the Greek model of capitalism. As we will argue, the Greek model of capitalism was shaped by the power of the ideas of the country's political leaders since 1980s. These ideas influenced the characteristics of the Greek model of capitalism creating a rather exceptional institutional framework unable to support long-run economic growth in the country. This exceptionalism is associated with an institutional asymmetry in relation with other member states and characterizes the Greek model of capitalism not only as the main cause for the economic crisis, but also as a significant obstacle to any recovery efforts, especially during COVID-19 pandemic.

In the first section of this article, we will study the theoretical framework of the varieties of capitalism, while in the second section, we will highlight the main characteristics of the Greek model of capitalism during the period of 1980-2009. In the third and fourth sections of this article, we will evaluate the economic crisis and the current COVID-19 pandemic and then we will reach into the main conclusions. 


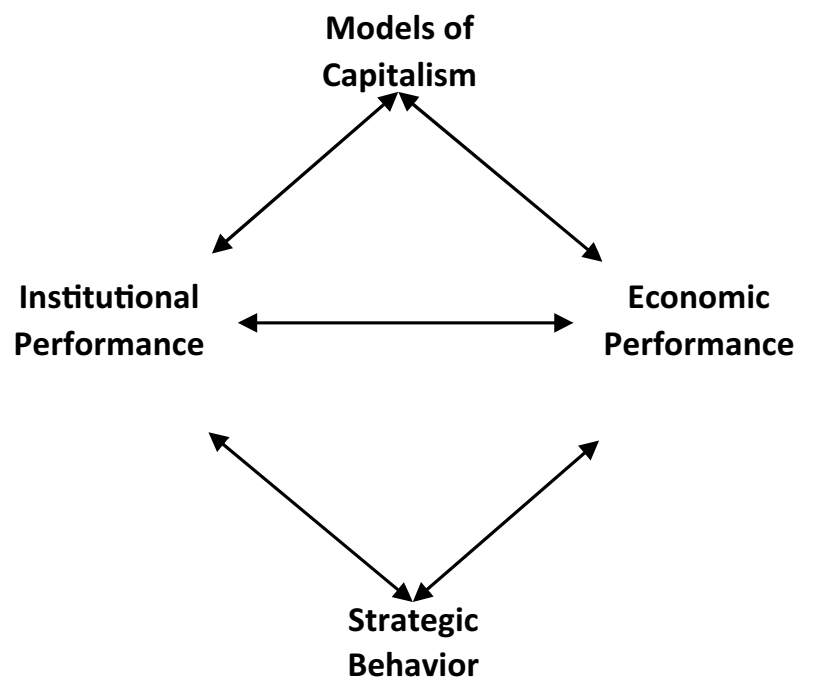

Fig. 1 Varieties of capitalism and strategic behavior. Source: Authors 2021

\section{Analyzing the varieties of capitalism: the theoretical approach}

The varieties of capitalism seek to shed light on whether differences between the institutional characteristics of states can affect their economic performance (Hall and Soskice 2001; Schmidt 2002; Amable 2003). In this regard, it is exactly this diversity of capitalist models that imposes restrictions not only on the economic efficiency of states, but also on finding appropriate strategies to overcome an economic crisis (Hall and Soskice 2001). The formation of specific models of capitalism affects the functioning of institutions and the economic performance, as well as the strategic behavior (see Fig. 1). In this regard, the choice of model influence both institutional function and economic performance, and through them the country's preferences and strategic behavior: nationally, regionally, and globally. Thus, the institutional performance is not an isolated element, but it rather affects the economic performance multi-dimensionally (Acemoglu and Robinson 2012). Based on this hypothesis, the model acquires dynamic characteristics and should not be studied independently (Amable 2003).

Hall and Soskice (2001) published the first substantially comprehensive attempt to capture the characteristics of models of capitalism. In their book, which became a point of reference, Hall and Soskice (2001) essentially shaped the theoretical framework of varieties of capitalism based on the assumption that differences in national economic institutions create different opportunities for firms which diversify their strategies to exploit emerging opportunities. They focus primarily on four key actors: individual, firms, producer groups and governments. Firms are situated at the heart of their theoretical approach, and they are characterized as rational; they operate within five spheres to resolve emerging 
coordination problems: industrial relations, vocational training and education, corporate governance, inter-firm relations, and employees (Hall and Soskice 2001).

Based on the above hypotheses, Hall and Soskice (2001) distinguish national economies between two types of political economy, namely liberal market economies and coordinated market economies. The main difference between these two types of political economy is that in liberal market economies, the market institutions provide the necessary means to coordinate economic actors with each other. In contrast, in coordinated market economies, the coordination of economic actors takes place to a large extent beyond the mediation of market forces. In this respect, the institutions come to play a prominent role in resolving the coordination problems that arise in both types of political economy by substantially influencing the strategic capabilities of the actors. However, due to the differences that exist in the institutional frameworks of the states, significant and systematic differences are created in the business strategy for both the liberal and the coordinated market economies (Hall and Soskice 2001: 16). The existence of institutional complementarities plays an important role in the approach of Hall and Soskice (2001). The institutional complementarities, inherent in each state, emphasize that the coordination that takes place between the various spheres of political economy is analogous and relative. In this sense, as Hall and Soskice (2001: 18) argue, "institutional practices of various types should not be distributed randomly across nations." Instead, the existence of institutional complementarities implies that the links between the institutions affect the performance of the institutional framework (Hall and Soskice 2001; Hancké 2009).

During last two decades, the varieties of capitalism approach have been improved in various ways. Amable (2003) using a cluster analysis identified the diversity of capitalism in five institutional areas: product-market competition; wage-labor nexus and labor-market institutions; financial-intermediation sector and corporate governance; social protection and the education sector. In contrast to Hall and Soskice (2001), Amable (2003) proposed five different models of capitalism: the marketbased economies; social-democratic economies; Asian capitalism; Continental European capitalism and South European capitalism. Furthermore, Hancké et al. (2007) and Hancké (2009) published two edited volumes presenting some of the most interesting critiques and debates regarding the approach. Other scholars provided alternative theoretical frameworks that place at the epicenter of their analysis not the firms but rather the institutions (Bruff 2011; Bruff and Horn 2012). They propose considerable critiques which mention that even though it is useful to study variations of capitalism, it is not evident that distinct and discrete varieties of capitalism can be found (Hay 2020). In this regard, institutions should be treated as a mere part of economic environment, but as a "socio-political compromises established in historically specific conditions" (Amable 2016: 79). Thus, varieties of capitalism acquire a dynamic characteristic and the political leaders may attempt to change the model of capitalism to secure their preferences (for example the French model of capitalism) (Amable 2016; Amable and Palombarini 2009).

In our case, starting from the seminal work of Hall and Soskice (2001), Greece belonged neither to the liberal nor to the coordinated market economies, but rather 
to a special case described as "Mediterranean". The Mediterranean cluster (Italy, Spain Portugal and Greece) has unique characteristics such as the regulated product markets, the regulated labor markets, the bank-based system, the limited welfare state and the weak education system (Amable 2003). According to Amable (2003), Greece is characterized by public sector, labor regulations, limited employment policies, limited training initiatives and rigid markets. The Mediterranean cluster is also characterized by a large agricultural sector and long periods of extensive state intervention which certainly affected the economic coordination capacity, their labor relations as well as the levels of innovation (Hall and Soskice 2001: 21). Few years later, prominent scholars have also used varieties of capitalism to examine the Greek case. Kevin Featherstone (2008) using neo-corporatism, varieties of capitalism and welfare approaches tried to identify Greece's failure to adopt and implement reforms. In addition, Pagoulatos and Triantopoulos (2009) underlined the credibility and the characteristics of the bank-based Greek model of capitalism and the underdevelopment of the Greek financial system. Furthermore, Voskeritsian and Kornelakis (2011) examined the institutional framework changes in the labor market as imposed by the Memorandum of Understanding and the related agreements. In this respect, Sklias and Maris (2013) argued that the institutional characteristics of the Greek crisis will exacerbate economic recession, and it is rather impossible to overcome from the crisis as soon as it was believed. Besides, there is always the possibility the Greek market to be transformed into a dysfunctional liberal economy (Kornelakis and Voskeritsian 2014). It is also evident that the initiation by the Greek government regarding the improvement of employment protection reforms were halted (Zartaloudis and Kornelakis 2017). In parallel, during the same period, other prominent scholars tried to enrich the existed framework of the varieties of capitalism approach in examining the Euro crisis (Hall 2014, 2018; Johnston and Regan 2016).

\section{The development of the Greek model of capitalism, 1980-2009}

In Greece, after the dictatorship period of 1967-1974, the return to the parliamentary democracy followed rather smoothly; while at the same time, the political ground was open for the development of new political forces and changes. Thus, a widespread demand skillfully exploited by PA.SO.K. (the Panhellenic Socialist Movement), which eventually managed to impose itself as a dominant force (Lyrintzis 1987). The first period concerns 1981-1989, when the elections of October 21, 1981 marked the rise of PA.SO.K. to power in Greece, taking over the government from the New Democracy party. Andreas Papandreou, founder, and leader of PA.SO.K., was sworn in as prime minister and a new period of a socialist government began with the main orientation to change established practices related to the culture of society and coordinated actions related to stakeholders.

Greece's total (domestic and foreign) debt in 1981 was recorded as $39 \%$ of country's Gross Domestic Product (GDP) and following a steady upward trend throughout the 1980s, it finally reached the $93 \%$ of country's GDP at the end of 1989. Thus, the total public debt of the country as a percentage of GDP was finally more than 
doubled within less than 10 years' period. In absolute terms, country's total public debt increased tenfold from 2.2 billion euros in 1981 to around 23 billion in 1989, with Greece being ranked first in the world in its per capita public debt.

During this period, the growth rate of public debt in Greece was mostly due to the high primary budget deficits amounting to around 6.6\% of country's GDP on average. In 1985, the first program of stabilization of the economy was decided, which lasted for about 2 years with a short restraint of the public deficit, when Greece finally entered a period of political instability and the deficit rose again at around $11.5 \%$ of GDP in 1988. The difference between country's almost stagnant revenues compared to the ever- increasing social expenditures of country's governance by PA.SO.K., both in absolute numbers per pension and in the expansion of the number of beneficiaries, were mainly due to the efforts to cover health care, welfare and increased social security needs. Finally, both welfare and health were probably the main reasons for the widening of the primary deficit and public dept at that time.

The socialist government of Greece brought changes in almost all sectors and aspects of the economic and social life of the country. Unfortunately, there was a lack of restrained management of public spending by the socialist government to satisfy its voters (Lyrintzis 1987), who reciprocated with the necessary tolerance for the actions of the government, and they also provided a positive vote during the electoral contests. The leading physiognomy of the founder and president of the Socialist Movement gave a unique identity to PA.SO.K., where decisions were always taken in agreement and with the blessings of Andreas Papandreou and in no case against his will ${ }^{1}$ with improvisations and exercise of power as a personal matter of the same (Featherstone and Papadimitriou 2015).

The subsequent period 1989-1990 is characterized by constant unrest and discussions about political and financial scandals in the country. There was a general anomaly in the political life of the country, with successive electoral contests (June 1989, November 1989). Eventually, an ecumenical government ${ }^{2}$ was formed under the chairmanship of the academic Xenofontas Zolotas. This governmental period can only be considered as a temporary one with mainly a managerial scope. Any attempt for a political decision by the government was temporarily and short-term planned, with the postponement of any necessary actions and reforms needed to streamline the economy and operation of the state. The character of the government as ecumenical seems to have been only formal, because the participants in the coalition had as their main goal their political survival and desire to rise to power and the

\footnotetext{
1 At the PASOK congress, it was decided to institutionalize the position of secretary of the Central Committee. Papandreou sees this position as a means of expressing and conveying his line and obviously wants to appoint a man of his trust. The opposition, led by Simitis and Mercouri, speaks openly of a coup d'etat. And the support within PASOK is not only negligible. Andreas is on the ropes for the first time: if the post of Central Committee secretary is not taken by a man of his own, he will not automatically command his party - and let him (formally) be its leader. In this regard, as it was stated "If Akis does not come out, I will dissolve PASOK and go for a new party" Papandreou is said to have stated in a historical process in Pentelikon: the internal party situation is at its worst (Charalambidis 1993).

2 The term Ecumenical Government in Greek political history refers to the government, in which theoretically all the party-political formations of the country participate, in a given period of time.
} 
weakening of the opposing parties. Therefore, this period can only be considered as intermediate and temporary for the needs of the present study about the appropriate model of capitalism.

The subsequent period 1990-1993 began with the elections of July 19, 1990, when the New Democracy party finally won the autonomy in the Greek Parliament and Konstantinos Mitsotakis was sworn in as the Prime Minister of the country. During that period, an attempt was made to carry out reforms with a liberal ideological character, but it was finally proven not possible to last for long. The country's total debt increased by around $27 \%$ of GDP and eventually the public debt amounted to $110 \%$ of country's GDP. The effort of any reforms appeared as a necessity coming from the European Union (EU) and for the purposes to avoid country's bankruptcy, and it finally felt into the void with the main reason the obligation to repay the high interest rates of the country's debt.

At that time, the government of Konstantinos Mitsotakis failed in staying longer in power due to several national issues that dominated country's political life, with the most important that of the Greekness of Macedonia. Eventually, and as expected, the slim majority held by New Democracy government in the Greek parliament did not allow to complete its 4-year term; so the country was led to elections again. The government of the country during that period did not enjoy the best possible acceptance of the social strata, since almost all its decisions took place in a topdown direction and without the almost necessary convergence of the social partners in issues related to labor, benefits, welfare, and education. Konstantinos Mitsotakis had been elected in the leadership of the New Democracy party as the appropriate politician who would be able to bring the party in power against his political opponent Andreas Papandreou. During the 3 years' governmental period, there have been many instances where neoliberal government policy moved at a faster pace than what society was able to realize and absorb; that created a gap of understanding and oneness. The governmental actions of Konstantinos Mitsotakis seemed to be a mixture of tradition and innovation and have been influenced by the standards of Greek political culture in which he resided for several decades (Featherstone and Papadimitriou 2015). However, the proclaimed neoliberal policy of Konstantinos Mitsotakis governance was found to be reminiscent of a more conservative regime in several cases because many of actions and political decisions were characterized by statehood and bureaucracy. For example, the criminalization of non-payment of debts to the state, the need to register with the insurance company as a condition for starting any business activity, the mandatory visa of any kind of private contract by the local competent tax authorities.

The 1993-2004 period began with the elections of October 1993, when the PA.SO.K. returned in power and the government of Andreas Papandreou ruled the country until January 1996, when he finally resigned from president of the movement due to his illness. At that time, Konstantinos Simitis was elected by the Parliamentary Group of PA.SO.K. and he subsequently took over as Prime Minister and he won the next electoral contests in September 1996 and April 2000. That period is characterized by a shift in the hitherto known form of the socialist model of government from PA.SO.K. in Greece. In particular, the Konstantinos Simitis governance put its attention on coordinated efforts aimed at taming public spending and deficits. 
The goal was the fiscal consolidation of the country due to the obligation to implement the convergence program for the final accession of the country to Economic and Monetary Union (EMU) and the adoption of the common currency of euro. Budget deficits had been one of the main criteria for inclusion of Member States in EMU, as described in the Maastricht Treaty (Maris et al. 2021).

Konstantinos Simitis was characterized as the most administratively adequate Prime Minister of the period after 1974, driven by the necessity to deal with the "internal party babel" in the PASOK movement. Although strongly related to German culture due to his previous professional experience, the country's governance model was in reality quite similar to that of the Dutch model. He is known for his institutional commitment to several services that were established and finally became decentralized (Featherstone and Papadimitriou 2015).

The last period covered by this study is that of 2004-2009: in the electoral contest in March 2004, the New Democracy party won and Kostas Karamanlis took over as the country's prime minister, also following the next elections in September 2007, where the party of New Democracy won again.

The model of capitalism of liberal market economies which was adopted during the 5-year rule of Kostas Karamanlis did not ultimately prevent the deviation from the main goal to reduce country's public debt. The so-called financial inventory in 2005 finally reported the public debt of 2000 increased by $8 \%$ due to the different method of recording defense spending. Then, although the public debt initially decreased during the first two years of government and it was recorded as $95 \%$ of GDP, the economic figures in the following years 2008-2009 were derailed and public debt finally amounting to almost $127 \%$ of GDP. The main reason that aggravates the situation is the imbalance between the general revenues and expenditures of the budget, the difference of which during the period 2003-2009 was estimated at 20 billion euros to burden the state budget. The unprecedented budget diversion seemed to be mainly due to the state budget, the deficit of which has doubled in the last 2 years and finally reached $13 \%$ in 2009, compared to a target of a deficit of $3.4 \%$ of GDP. At the same time, it changed from 1.4\% of GDP in 2008 to $7.8 \%$ in 2009 , while the revised target was for a primary deficit of $0.2 \%$ of GDP (Bank of Greece 2010).

Kostas Karamanlis did not manage to take advantage of his extremely high popularity in an effective governmental policy. His leadership profile was similar to a president since the degree of freedom he had given to his ministers were very high. Ultimately, governmental work was based on the principle of diffusion of responsibility, which, however, led to a malfunction of the core of government (Featherstone and Papadimitriou 2015).

During the 1980-2009 period, the form of capitalism that was declared by the leadership of each ruling party - within the range of liberal and coordinated-was quite different from the real one, which was finally applied in the field of politics. It is not easy to have the type of the model of capitalism distinguished and classified in a category. For the Greek case, the model of capitalism seems like an idiosyncratic mixture that is shaped and guided to a large extent by the leading physiognomy and personality of the leader of each ruling party. 
The implemented policies of Andreas Papandreou, Konstantinos Mitsotakis, Konstantinos Simitis and finally Kostas Karamanlis during the period 1980-2009 do not seem to escape from this finding, but on the contrary the personality and philosophy of each leader finally influenced their capitalist model of government. It is finally seen that the effort to manage and reduce public spending is always crucial and one of the key components for an effective policy mix that must be considered

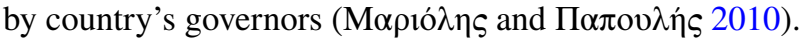

Finally, it seems that there is no real application of a particular type of capitalism in Greece as at least one experiences it in other foreign countries, but the real capitalism in Greece seems to be a peculiar form, adapted to the characteristics of the leader of the ruling party and the requirements to be met to the stakeholders for the purpose of government viability. In the case of Greece, the political leaders influenced with their ideas and personality the model of capitalism during the last four decades, bringing about an irregular and peculiar model of capitalism, adapted to the idiosyncrasy and the culture of the political life of the country. Table 1 is characteristic of the type of capitalism declared by the Greek leaders prior the elections and the model that implemented from 1981 to 2019.

In addition, this different and distinct model of capitalism in Greece seems to have been distorted, because it did not provide real opportunities for differentiation and competition with other countries in the region and the EU members. On the contrary, there have been long periods of extensive state intervention that had certainly affected the economic coordination capacity. In principle, the Greek political leaders affected the main forces that decisively influenced the formation of the peculiar model of capitalism in Greece. Thus, varieties of capitalism acquire a dynamic characteristic and the political leaders may attempt to change the model of capitalism to secure their preferences as some of them prefer and like a variation type of the French model of capitalism.

\section{The economic crisis and the new model of capitalism in Greece, 2009-2020}

In 2008, the failure to rescue Lehman Brothers was the critical and major event that finally led to the global financial crisis (Skeel 2018). The following consequences hit each country and all economies around the world including Greece which happened not to be the exemption to that. On the contrary and as it was expected, Greek economy faced tremendous financial problems that became severe since 2008 afterwards as the size of the budget deficit was at $15.2 \%$ of country's GDP and international markets were not willing to borrow cheap money to Greece anymore, as happened in the past which had contributed to the latent growth of the country during the previous decades (Hardouvelis and Gkionis 2016). In 2010, the global markets and banking sector appeared unwilling to continue borrowing to Greece, so the country reached a dead end and it was isolated with inability to access money in order cover its fixed and regular needs in key areas of public life and for the continued functioning of the government and the country. Fears of a general unrest were 


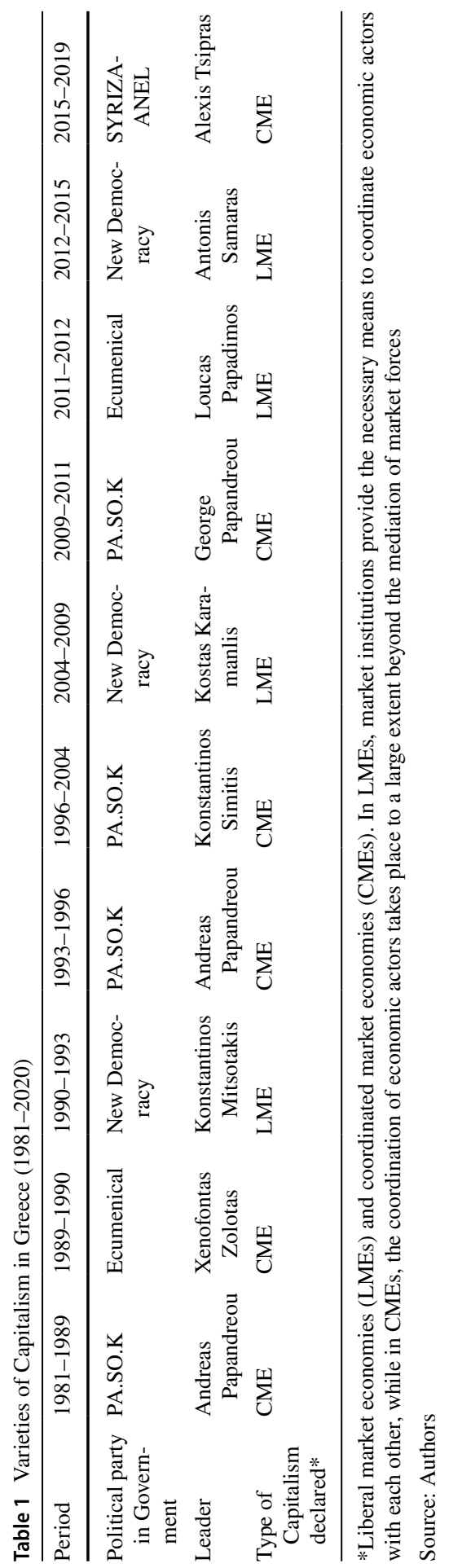




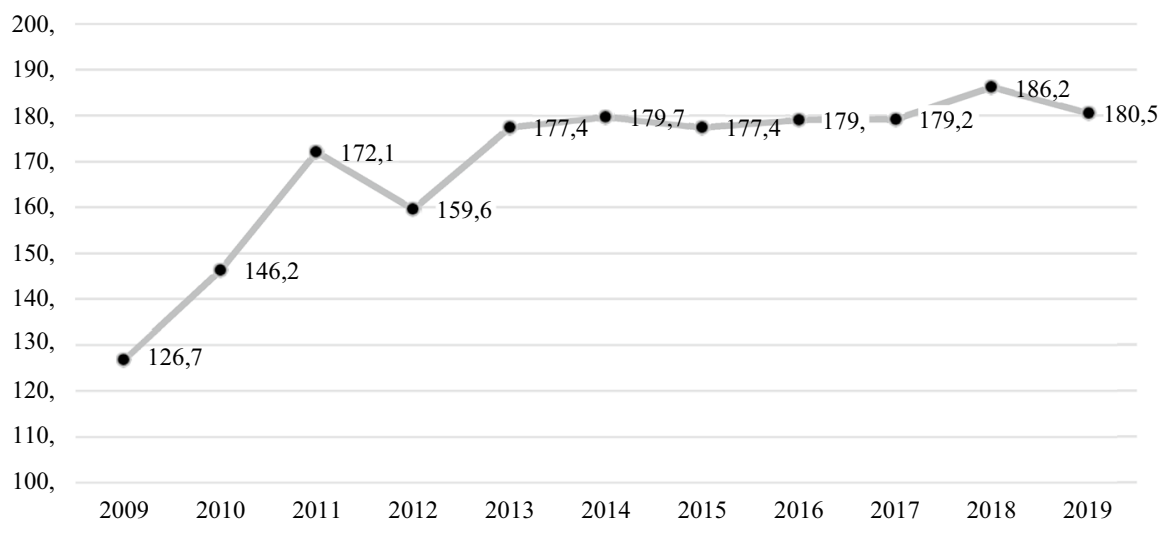

Fig. 2 Greece's General government gross debt \% of GDP during 2009-2019

already evident, with protests and demonstrations on the agenda of the country's political life.

The result is known, and the country requested for external support and help; finally, it received a huge financial aid from three international institutions, named as the Troika:

(i) the EU, (ii) the European Central Bank (ECB) and (iii) the International Monetary Fund (IMF). The total financial aid that Greece succeeded to get was 239 billion Euros through three separate Memorandums in the years 2010, 2012 and 2015, that were immediate and radical Economic Adjustment Programmes.

Greece's general government gross debt as a percentage of its GDP during the period 2009-2019 is given in the Fig. 2, where it is clearly seen that after three consecutive Memorandums and 10 year's period of strict austerity measurements, the general government gross debt of the country increased by $53.8 \%$ debt as a percentage of its GDP.

The extraordinary austerity measurements and financial adjustments seem to have been implemented in an unusual and unsustainable way. Capital spending and recurrent spending were cut to levels that hamper potential growth and the provision of basic public services and increases in already high tax rates caused further deterioration in already low current tax collection rates (Thomsen 2019). Cutting wages and pensions dramatically affected personal income and families found it difficult to cover their monthly expenses and utility bills. There was a general refusal to face the reality and the new unexpected crisis that directly affected the economic and social life of the country. That reflected also to lack of political support for reforms as each party preferred to avoid appearing unfriendly and social analgesic.

During all this period, the austerity program was totally opposed from day one by all opposition parties in the Greek parliament and in many cases even from within the ruling party. After the two first Memoranda, the dissatisfaction and misconception of citizens and society created a wave of protest against the leaders and those in charge of the political and economic life of the country. The political opponents of the current ruling party credited the anger and resentment of people, trying to rise 
to power themselves, promising better days and a way out of the memoranda. In this way, the coalition of two parties SYRIZA and ANEL managed to rise to power in 2015 and finally to agree to the signing and implementation of the third Memorandum in the country (Thomsen 2019).

Regarding the consequences and influences of the Memoranda in the political life of the country, the Memoranda are considered informal international agreements (arrangements) of a simplified form and, therefore, do not require sanction as provided otherwise in accordance with the provisions of the Constitution (article 28 paragraphs 1-3 and article 36 paragraph 2). Also, the Memoranda do not contain legal obligations, but also rules of law that can apply directly in the Greek legal order and therefore do not create obligations or rights to Greek citizens since as nonlegal texts they constitute a form of mild law that has no regulatory content (Manitakis 2011).

Based on the previous experience and implementation of the Memoranda in Greece, where a drastic cut in public spending took place, with horizontal measures aimed at creating a healthy and sustainable business environment with the least possible state intervention. That one brings the Greek model of capitalism closer to the liberal one. However, as it finally turned out, this strategy is proved as insufficient to deal with the Greek debt crisis properly and effectively. The main reason for that seems to be the impossibility of a correct view of the Greek reality and the current model of capitalism in Greece, a fact that relates to the institutional interdependence that is observed in the Greek field (Xó $\rho \delta \alpha \varsigma 2015)$.

\section{COVIC-19 pandemic and the Greek model of capitalism}

The COVID-19 pandemic has been originated from the coronavirus SARS-CoV-2 which appeared in Greece on February 26, 2020, and then spread throughout the country. The effects of this unforeseen catastrophic event have already been perceived and its results on each country, including Greece will be severe and will cause structural changes even in the short term (for an excellent analysis regarding the performance of Greek economy during COVID-19 pandemic, see Mariolis et al. 2021).

The small size of Greek companies at all levels when compared to those of small and medium-sized (SMEs) enterprises in the Eurozone has a negative impact on the effort to increase their productivity and it is a form of weakness to achieve economies of scale and enhance the extroversion in the global business environment and international markets. Unemployment and low levels of employment also negatively affect the growth and the economy of the country with the percentage of the economically active population in Greece, aged 15-64, remaining consistently below the EU average (for employment policy performance in Greece, see Plimakis et al. 2021). In particular, the low labor force participation rate is found mainly among women and young people aged 15-24, who with $22.5 \%$ show the lowest rate compared to $39.4 \%$ of the EU. An additional challenge for Greece is the regional disparities within the territory where the regions of the North Aegean and the Ionian Islands to record the lowest GDP in the Greek territory in recent years. 
Greek economy is mainly characterized by the public sector, labor regulations, limited employment policies, limited educational initiatives and rigid markets (Liargovas 2000). The chronic pathogenesis of the Greek reality is also related to the fact that Greek politicians act in favor of public sector unions and treat them with privilege compared to other employees. At the same time, Greek political parties have not been obeying a proper, clear action plan but on the contrary, each governmental action seems to be fragmented, isolated, and aimed at analyzing current problems without supporting any vision for the country (Liargovas and Kratimenou 2021).

New challenges that have been already emerged due to the COVID-19 pandemic and which are expected to remain in the future include an increase in engagement in digital home activities, a quality upgrade of IT services available for the users, a change in communication and socialization with unpredictable consequences especially at young age. In addition, the new working model in EU and also in Greece seems to change to working remotely. Such a change is expected to cause many implications in different areas such as labor law with the inclusion of a more flexible form of work, the tax regulation that need to be updated and finally the modern way of life of the Greek citizen in the globalized environment. In regards to tax regulation in Greece, there is a blend of measurements taken by the government as announced with the Law 4797/2021 such as special regulation for the tax year 2020 , regarding the alternative way of calculating the minimum tax, for specific categories of taxpayers, whose incomes were affected in 2020 by the COVID-19 pandemic, low-income tax relief, tax exemption for socially vulnerable groups, subsidy of social benefits to special groups of the population, special purpose compensation to companies that have been financially affected and its exemption from taxable income.

Contrary to the case where internal factors played the main and decisive role in shaping a unique and special model of capitalism in Greece, there are external factors now as the main cause that influence the form of the newer model of capitalism in the country. A more inclusive economy where technology and Internet of Things (IoT) are expected to bring radical changes in the industry in a world that will be still interconnected, and precautions are taken to ensure that mental health of workers and citizens are secured and protected. The films are re-designing their systems and chains to diversify the risk of unforeseen dangers such as the pandemic and ensure that it will have less impact on them in the future, while governments have to address the fact that requirements related to accommodation, healthcare and education becoming more necessary and costly also. The latest global financial crisis and the subsequent health pandemic crisis are threats driven from the external environment of the country. Unfortunately, the country is hardly prepared to confront and deal with them effectively, at least in the long run.

The already distorted and rather exceptional institutional framework of Greece, as well as the chronic pathogenesis of the political and social system of the country, have been found as not capable to protect the country against such global crises, which were admittedly unpredictable, very strong and cataclysmic. The external environment seems to bring new situations and traditions, which, although they impose the change of laws and rules in the political, economic and social life of the 
country, still do not manage to change much the culture of the politicians and the leaders of the country.

\section{Conclusions}

As discussed, and presented in this paper, the Greek model of capitalism was mainly shaped by the power of the ideas of the country's political leaders after the restoration of the newest parliamentary democracy in the country and during the last 40 years in the political life. The political leaders of the parliamentary parties and those who were trying to enter into the parliamentary life of the country, influenced with their ideas their parties and consequently the government policies that were implemented during the period 1980 until today. As a result, their ideas influenced the functioning of the country's institutions and the capitalist model of the country, creating a peculiar, mixed model with a distorted structure and institutional framework.

These ideas affected the characteristics of capitalism in Greece creating a rather exceptional institutional framework unable to support long-run economic growth in the country. In this regard, the exceptional model of capitalism, adapted to the idiosyncrasy and the culture of the political life of the country characterizing at the same time the role of the state and the markets, i.e., long periods of extensive state intervention or failure to implement reforms. This exceptional model of capitalism in Greece seems to have also been distorted, because it did not provide real opportunities for differentiation and competition with other countries in the region and the member states of EU. Thus, Greek exceptionalism is also associated with an institutional asymmetry in relation with other member states and at the same time characterizes Greek capitalism not only as the main cause for the economic crisis, but also as a significant obstacle to any recovery efforts, especially during COVID19 pandemic.

The emergence of the unexpected pandemic caused an unprecedented state of emergency and brought about a drastic change and adaptation of hitherto proposed government policies to the new reality. Collective response to deal with the pandemic is a necessity, both within the country and at the European level of cooperation between countries. The COVID-19 pandemic brought new challenges that are expected to become permanent and remain also in the near future. Such radical changes include a new holistic health system and responsible citizens, increase in engagement in digital home activities, a quality upgrade of technological state of the art services available for the users, a change in communication and socialization with unpredictable consequences especially at a young and young age. Furthermore, a new working model has been already applied, where employees and entrepreneurs work remotely more than before, which will affect many institutions in the country and the lifestyle in the communities.

\section{Declarations}

Conflict of interest The authors state that there is no conflict of interest. 
Ethical approval This article does not contain any studies with human participants or animals performed by the author.

\section{References}

Acemoglu D, Robinson JA (2012) Why nations fail: the origins of power, prosperity and poverty. Crown Publishers, New York

Amable B (2003) The diversity of modern capitalism. Oxford University Press, Oxford

Amable B (2016) Institutional complementarities in the dynamic comparative analysis of capitalism. J Inst Econ 12(1):79-103. https://doi.org/10.1017/S1744137415000211

Amable B, Palombarini S (2009) A neorealist approach to institutional change and the diversity of capitalism. Socio-Econ Rev 7(1):123-143. https://doi.org/10.1093/ser/mwn018

Bank of Greece (2010) Annual Report 2009. Bank of Greece, Eurosystem

Bruff I (2011) What about the elephant in the room? Varieties of capitalism, varieties in capitalism. New Polit Econ 16(4):481-500. https://doi.org/10.1080/13563467.2011.519022

Bruff I, Horn L (2012) Varieties of capitalism in crisis? Compet Change 16(3):161-168. https://doi.org/ 10.1179/1024529412Z.00000000011

Charalambidis M (1993) PASOK: the conflict of the new with the old. Gordios, Athens

Featherstone K (2008) Varieties of capitalism and the Greek case: explaining the constrains on domestic reform. GreeSE Paper No. 11, Hellenic Observatory, London School of Economics, London

Featherstone K (2011) The JCMS annual lecture: The Greek sovereign debt crisis and EMU: A failing state in a skewed regime. J Common Mark Stud 49(2):193-217. https://doi.org/10.1111/j.14685965.2010.02139.x

Featherstone K, Papadimitriou D (2015) Prime ministers in Greece: the paradox of power. Oxford University Press, Oxford

Hall PA (2014) Varieties of capitalism and the Euro crisis. West Eur Polit 37(6):1223-1243. https://doi. org/10.1080/01402382.2014.929352

Hall PA (2018) Varieties of capitalism in light of the euro crisis. J Eur Publ Policy 25(1):7-30. https://doi. org/10.1080/13501763.2017.1310278

Hall PA, Soskice D (2001) Varieties of capitalism. The institutional foundation of comparative advantage. Oxford University Press, Oxford

Hancké B (2009) Debating varieties of capitalism: a reader. Oxford University Press, Oxford

Hancké B, Rhodes M, Thatcher M (2007) Beyond varieties of capitalism: conflict, contradictions, and complementarities in the European economy. Oxford University Press, Oxford

Hardouvelis G, Gkionis I (2016) A Decade long economic crisis: Cyprus versus Greece. Cyprus Econ Policy Rev 10(2):3-40

Hay C (2020) Does capitalism (still) come in varieties? Rev Int Polit Econ 27(2):302-319. https://doi.org/ $10.1080 / 09692290.2019 .1633382$

Johnston A, Regan A (2016) European monetary integration and the incompatibility of national varieties of capitalism. J Common Mark Stud 54(2):318-336. https://doi.org/10.1111/jcms.12289

Kornelakis A, Voskeritsian H (2014) The transformation of employment regulation in Greece: towards a dysfunctional liberal market economy? Relat Industrielles 69:344-365. https://doi.org/10.7202/ 1025032 ar

Lapavitsas C (2019) Political economy of the Greek crisis. Rev Radic Polit Econ 51(1):31-51. https://doi. org/10.1177/0486613417730363

Liargovas P (2000) The changing role of the Greek state in view of the European Monetary Union. In: Mitsos A, Mosialos E (eds) Contemporary Greece and Europe. ASHGATE Press, London, pp 205-221

Liargovas P and Kratimenou V (2021) "The Economic Adjustment Programs of Greece (2010-15): Why Failure?. In: Beate S, Georgina T, Charlotte V (Eds) Sustainable Value Creation: A Multidisciplinary Analysis in the Context of the EU's Social Market Economy, Cambridge University Press, Forthcoming 2021

Lyrintzis C (1987) The power of populism: the Greek case. Eur J Polit Res 15:667-686 
Manitakis A (2011) The constitutional issues of the Memorandum. Human rights DTA No. 51/2011: 689-719. Available at https://www.constitutionalism.gr/wp-content/uploads/2013/08/2013.08_ Manitakis_Syntagmatika.zitimata.mnimoniou.DtA2011.pdf. Accessed 15 Apr 2021

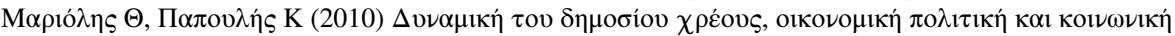

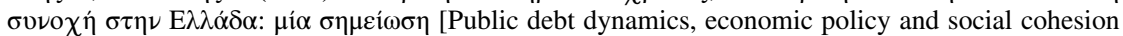

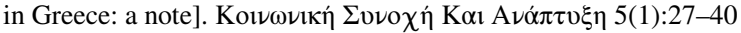

Mariolis T, Rodousakis N, Soklis G (2021) Inter-sectoral analysis of the Greek economy and the COVID19 multiplier effects. Eur Polit Soc. https://doi.org/10.1080/23745118.2021.1895555

Maris G (2021) Introduction: Eurozone and the Greek economic crisis in 2020: current challenges and prospects. Eur Polit Soc. https://doi.org/10.1080/23745118.2021.1895551

Maris G, Sklias P, Maravegias N (2021) The political economy of the Greek Economic crisis in 2020. Eur Polit Soc. https://doi.org/10.1080/23745118.2021.1895552

Pagoulatos G (2020) EMU and the Greek crisis: testing the extreme limits of an asymmetric union. J Eur Integr 42(3):363-379. https://doi.org/10.1080/07036337.2020.1730352

Pagoulatos G, Triantopoulos C (2009) The return of the Greek patient: Greece and the 2008 global financial crisis. South Eur Soc Polit 14(1):35-54

Plimakis S, Maris G, Masouras A, Galanos G, Karachalios G (2021) EU Structural funds and employment policy performance in Greece: impact and reform during the fiscal austerity years. Eur Polit Soc. https://doi.org/10.1080/23745118.2021.1895556

Schmidt V (2002) The future of European capitalism. Oxford University Press, Oxford

Skeel D (2018) History credits Lehman Brothers' collapse for the 2008 financial crisis. Here's why that narrative is wrong. Report from Brookings Institute. Available at https://www.brookings.edu/resea rch/history-credits-lehman-brothers-collapse-or-the-2008-financial-crisis-heres-why-that-narrativeis-wrong/. Accessed 15 Apr 2021

Sklias P, Maris G (2013) The political dimension of the Greek financial crisis. Perspect Eur Polit Soc 14(1):144-164. https://doi.org/10.1080/15705854.2012.732392

Thomsen P (2019) The IMF and the Greek crisis: myths and realities. Speech by Poul Thomsen. Available at https:/www.imf.org/en/News/Articles/2019/10/01/sp093019-The-IMF-and-the-Greek-Crisis-Myths-and-Realities. Accessed 15 Apr 2021

Voskeritsian H, Kornelakis A (2011) Institutional change in Greek industrial relations in an era of fiscal crisis. GreeSE papers (52), London School of Economics and Political Science, Hellenic Observatory, London, UK

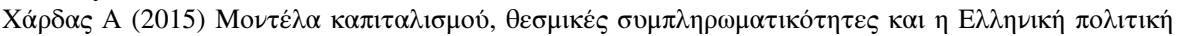

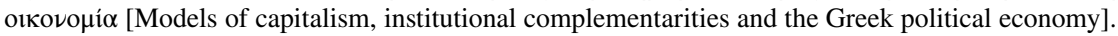

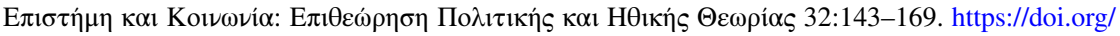
$10.12681 /$ sas.567

Zartaloudis S, Kornelakis A (2017) Flexicurity between Europeanization and varieties of capitalism? A comparative analysis of employment protection reforms in Portugal and Greece. J Common Mark Stud 55(5):1144-1161. https://doi.org/10.1111/jcms.12533

Publisher's Note Springer Nature remains neutral with regard to jurisdictional claims in published maps and institutional affiliations. 